
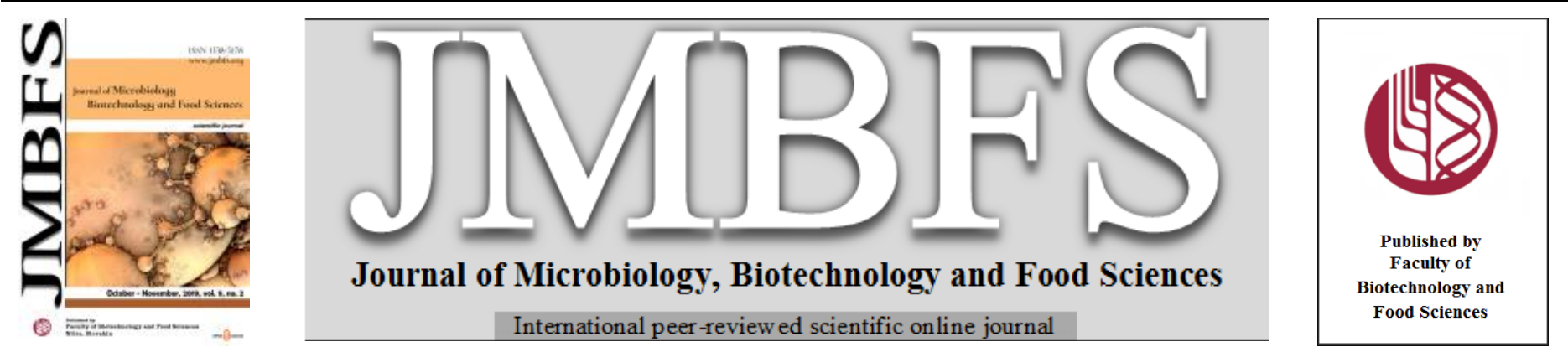

\title{
PHYTOCHEMICAL ANALYSIS, ANTIOXIDANT AND ANTIMICROBIAL ACTIVITIES OF THREE SAMPLES OF DRIED FIGS (FICUS CARICA L.) FROM THE REGION OF MASCARA (WESTERN ALGERIA)
}

\author{
Souhila BENMAGHNIA ${ }^{1}$, Boumediene MEDDAH ${ }^{1,2}$, Aicha TIR-TOUIL ${ }^{1}$ and José Antonio GABALDÓN HERNÁNDEZ ${ }^{3}$
}

\section{$\operatorname{Address(es):~}$}

${ }^{1}$ Bioconversion, Microbiological engineering and Health safety, SNV Faculty, Mascara University, Algeria. atirtouil@yahoo.fr

${ }^{2}$ Equipe Thera., Laboratoire des glucides- FRE-CNRS 3517, UFR de Pharmacie, Université de Picardie, Amiens, France. meddah19@ yahoo.fr

${ }^{3}$ Head of REM research group, Catholic University of Murcia, Spain. jagabaldon@ucam.edu

*Corresponding author: souhila.benmaghnia@univ-mascara-dz

doi: 10.15414/jmbfs.2019.9.2.208-215

\section{ARTICLE INFO}

Received 12.1.2019

Revised 25. 3. 2019

Accepted 26. 3. 2019

Published 1. 10. 2019

Regular article open $\partial_{\text {ACCESS }}$

\begin{abstract}
Ficus carica $L$. have always been known by their power to cure various diseases. This study aims to evaluate the antioxidant activity of twelve different extracts of three samples of dried figs. First, the extracts were tested for their polyphenolic, flavonoid and tannin contents by the Folin-Ciocalteu, the aluminium trichloride and vanillin methods and high-performance liquid chromatography (HPLC) for more characterisation. The antioxidant activity was performed by using thre different methods; the 2,2-diphenyl-2-picrylhydrazyl (DPPH), Ferric reducing antioxidant power (FRAP) and total antioxidant capacity (TAC). The results showed that the methanolic extract of Sidi Bendjebbar sample presented a higher TPC value $(458 \mathrm{mg} \mathrm{GAE} / \mathrm{g}$ ) while the acetonic and aqueous extracts of El-Keurt presented a higher values of TFC and CTC. In other hand, the methanol extract of El-Keurt sample exhibited the highest antioxidant capacity with an IC 50 of $0.078 \mathrm{mg} / \mathrm{ml}$. The antimicrobial activity of the extracts against various Gram positive and Gram negative bacteria was screened by the inhibition zone using the disc and diffusion assay, minimal inhibition concentration (MIC) by micro-well method allonwing to calculate the fractional inhibitory concentration (FIC). The ethanolic extracts of the two samples El-Keurt and Sidi Bendjebbar were the most effective extracts being able to inhibit the growth of the majority of the strains tested. Our study supported the use of these fruit as supplements for nutrient deficiencies and for combating diseases associated with oxydative damage or some microbial infection for better drug alternatives.
\end{abstract}

Keywords: Ficus carica, polyphenols, antioxidant activity, antimicrobial activity, dried figs, MIC

\section{INTRODUCTION}

The fig tree (Ficus carica); Moraceae family; is the second emblem in the Mediterranean basin where it has been cultivated for millennia. The dried fruits of $F$. carica have been reported as an important source of nutritional elements as vitamins, minerals organic acids and phenols (Mawa et al., 2013). Previous studies have been performed on polyphenolic extracts of $F$. carica and reported numerous bioactive compounds i.e. phytosterols, organic acids, anthocyanin, triterpenoids, volatile compounds and coumarins (Oliveira et al., 2009, Nasar et al., 2014).

This Fruits are traditionally used to cure many diseases and as a stimulant, laxative, emollient, resolutive cough suppressant, emmenagogue (Guarrera, 2003) and for constipation, hemorrhoids and hypercholesterolemia (Cansaran and Kaya, 2010). These fruits have been able to increase antioxidant capacity in plasma not to mention their benefits on various disorders such as inflammatory, cardiovascular disorders, gastro-intestinal, respiratory, ulcerative diseases, and cancers (Vinson et al., 2005; Jasmine et al., 2014). Solomon and colleagues (2006) reported that $F$. carica fruits contains produces the highest antioxidant effect.

Biomolecules have always interested scientists working on infectious diseases highlighting plants with antimicrobial activity (Aswar et al., 2008). Infectious diseases continue to represent a critical problem to human health incresed using of antibiotics and vaccination programs (Adeshina et al., 2010). At present, many bacteria pose a huge problem because of the multidrug resistance that may have developed to the antimicrobial agents used against infections, making the discovery of new antimicrobial substances an undesirable action (Chanda and Kaneria, 2011).

Viewing the alternative properties of $F$. carica, our study deals with different extracts of dried figs grown in three different regions of Mascara (El-Keurt, Ain Fares and Sidi Bendjebbar) to investigate their phytochemical compounds and antioxidant activities to determinate finally the correlation between these activities to investigate their antibacterial activity against 14 bacteria.

\section{MATERIALS AND METHODS}

\section{Plant samples}

Dried figs were collected from local markets in the three regions (El-Keurt, Ain Farés and Sidi Bendjebbar) of Mascara during the month of December 2014. The varieties were confirmed by the Technical Institute of Mascara Fruit Trees (ITAF) after being selected according to market availability, the most frequent consumption and the altitude of the growing area.

\section{Preparation of the extract}

The extracts were prepared according to the modified method described by Jasmin and colleagues (2014). Aqueous and organic extracts were prepared from $50 \mathrm{~g}$ of the pulp macerated in $200 \mathrm{ml}$ of solvent (distilled water, $80 \%$ methanol, $70 \%$ ethanol and 50\% acetone) at room temperature and away from light for 24 hours, under agitation. Then, the mixture was filtered and concentrated with rotavapor at $40^{\circ} \mathrm{C}$ under vacum to obtain a dry extract permitting the calculation of the yield of each sample.

\section{Phytochemical Screening}

The qualitative characterization of the aqueous, methanolic, ethanolic and acetonic extracts was carried out according to Evans 1996 by chemical techniques and thin layer chromatography tests.

\section{Determination of total phenolics content}

The Folin-Ciocalteu method has helped to determine the TPC of Ficus carica extracts following to Singleton et al. (1999) with some modification. $20 \mu \mathrm{l}$ of each 
extract was diluted in $1.58 \mathrm{ml}$ of distilled water. An aliquot of the solution was added to $100 \mu \mathrm{l}$ of Folin-Ciocalteu reagent diluted in distilled $\mathrm{H}_{2} \mathrm{O}(\mathrm{v} / \mathrm{v})$ before adding $300 \mu \mathrm{l}$ of sodium carbonate $7.5 \%$. After 2 hours of incubation, protected from light, read the absorbance from the UV-visible spectrophotometer at $760 \mathrm{~nm}$. The blank is represented by methanol added to the Folin-Ciocalteu, distilled water and sodium carbonate. All measurements are repeated three times using gallic acid as a standard. The results were expressed as mg gallic acid equivalents (GAE)/100 g dried fruit.

\section{Determination of total flavonoids content}

Quantification of flavonoids (TFC) was carried out by a spectrophotometric method adapted Zhishen et al. (1999). $500 \mu$ taken from different concentrations of methanolic extract and catechin solution diluted in methanol were added to 1500 $\mu \mathrm{l}$ of distilled water and then mixed with $150 \mu \mathrm{l}$ of sodium nitrite ( $\mathrm{NaNO}_{2}$ ) at $5 \%$ and $150 \mu \mathrm{l}$ and $10 \%$ aluminum trichloride $\left(\mathrm{AlCl}_{3}\right) .500 \mu \mathrm{l}$ of sodium hydroxide (1 $\mathrm{M} \mathrm{NaOH}$ ) are added after incubation for 5-6 min. Absorbance was measured at $510 \mathrm{~nm}$ against white. The total flavonoid content of the extracts was expressed in milligrams (mg) of catechin equivalent per gram (g) weight of dry matter (EC) /g).

\section{Determination condensed tannins content}

The amounts of condensed tannins (CTC) are determined by the vanillin method (Julkunen-Titto, 1985). The vanillin solution was prepared by mixing in equal volume: $8 \% \mathrm{HCl}(\mathrm{v} / \mathrm{v}), 37 \%$ methanol (v/v) and $4 \%$ vanillin in methanol (w/v) The mixture was maintained at $30^{\circ} \mathrm{C}$ before assay (Ba et al., 2010). $50 \mu \mathrm{l}$ of each extract is mixed with $1500 \mu \mathrm{l}$ of vanillin / methanol solution and added to $750 \mu$ of concentrated hydrochloric acid $(\mathrm{HCl})$ to be incubated for $20 \mathrm{~min}$. Absorbance was measured at $550 \mathrm{~nm}$ against a blank consisting of a mixture of methanol (37\%) and $\mathrm{HCl}(8 \%)$ in equal volumes (Mahmoudi et al., 2013). The tannin concentration $\mathrm{s}$ determined in $\mathrm{mg}$ of catechin equivalent per gram $(\mathrm{g})$ of the dry matter weight (EC) / g).

\section{Determination of antioxidant activities}

\section{Total antioxidant activity}

Total antioxidant capacity (TAC) was tested by the phospho-molybdenum method Prieto et al. (1999). A series of solutions containing $0.3 \mathrm{ml}$ of the various extracts is added to $1.2 \mathrm{ml}$ of a reagent mixture $(0.6 \mathrm{M}$ sulfuric acid, $28 \mathrm{mM}$ sodium phosphate and $4 \mathrm{M}$ ammonium molybdate). The absorbance was measured at 695 $\mathrm{nm}$ (Puoci et al., 2011) after having incubated the mixture for $150 \mathrm{~min}$ at $95^{\circ} \mathrm{C}$ against the blank consisting of $0.3 \mathrm{ml}$ of methanol and $3 \mathrm{ml}$ of the previously prepared reagent. This activity was expressed in milligrams equivalents of ascorbic acid per gram of dry matter (mg AAE / g DM). The experience is repeated in triplicate (Isaac Kingsley Amponsah, 2012).

\section{DPPH radical-scavenging activity}

The determination of antioxidant activity by the DPPH (diphenyl 2.2 picrylhydrazyl 1) was determined by the method of Brand-Williams et al. (1995). Before starting, the DPPH solution using $0.0197 \mathrm{~g}$ of DPPH to dissolve in $100 \mathrm{ml}$ absolute methanol was prepared to have a solution of $0.5 \mathrm{mM}$. For all extracts dilutions were prepared in absolute methanol in order of micrograms per $\mathrm{ml}$. The solution of the test extract previously diluted with a Tris buffer solution $(0.1 \mathrm{M}$ $\mathrm{pH}=7.4$ ) was added to the DPPH solution. After agitation, the tubes are placed in the dark for 30 minutes. The absorbance was measured at $517 \mathrm{~nm}$ against the blank which was composed of $1 \mathrm{ml}$ of methanolic DPPH solution $(0.3 \mathrm{mM})$ and $1 \mathrm{ml}$ of the Tris solution. The positive control was represented by ascorbic acid, to calculate the $\mathrm{EC}_{50}$ effective concentration that reduces the initial concentration of $50 \% \mathrm{DPPH}$, the results were expressed as percent inhibition according to Wang and Mazza (2002):

$$
\% \text { Inhibition }=\{(\text { Abs contrôle }- \text { Abs test }) / \text { Abs contrôle }\} \times 100
$$

\section{Ferric reducing antioxidant power (FRAP)}

The iron-reducing activity of our samples was determined according to the method described by Oyaizu (1986). In a tube was mixed a volume of extract at differen concentrations, $2.5 \mathrm{ml}$ of $0.2 \mathrm{M}$ phosphate buffer solution ( $\mathrm{pH} 6.6$ ) and $2.5 \mathrm{ml}$ of potassium ferricyanide solution $\mathrm{K}_{3} \mathrm{Fe}(\mathrm{CN})_{6}$ to $1 \%$ before incubating at $50{ }^{\circ} \mathrm{C} / 20$ minutes. $2.5 \mathrm{ml}$ of $10 \%$ trichloroacetic acid was added to perform centrifugation at $3000 \mathrm{rpm}$ for 10 minutes. Finally, $2.5 \mathrm{ml}$ of the supernatant was reacted with 2.5 $\mathrm{ml}$ of distilled water and $0.5 \mathrm{ml}$ of a frechely prepared ferric chloride solution at $0.1 \%$. The absorbance was measured at $700 \mathrm{~nm}$ using a blank containing the constituents mentioned above except the extract which was replaced by distilled water. An increase in the absorbance corresponds to an increase in the reducing power of the extracts tested (Hubert, 2006).

\section{HPLC-DAD for phenolic profile determination}

The extracts were subjected to HPLC analysis on an HPLC system Agilent 1200 (USA) type with a diode array detector. Column Hichrom C18 (4.6 mm x $250 \mathrm{~mm}$, particle size of 5 microns). This device includes a column temperature of $40^{\circ} \mathrm{C}$ allowing an injection volume of $10 \mu \mathrm{l}$ to pass. The solvent system was a gradient of water-formic acide $(0.5 \%)(\mathrm{A})$ and methanol $(\mathrm{B})$. The gradient employed was: starting with $95 \%$ (A), from $95 \%$ (A) to $60 \%$ for $30 \mathrm{~min}$, from $60 \%$ (A) to $35 \%$ for $15 \mathrm{~min}$ at a flow rate of $1.0 \mathrm{ml} / \mathrm{min}$. The detection spectra of the polyphenols were noted at $280 \mathrm{~nm}$ and $320 \mathrm{~nm}$.

\section{Determination of the antibacterial activity}

\section{Test microorganisms}

Five gram positive bacteria Listeria innocua, Bacillus subtilis, Clostridium perfringens, Enterococcus faecalis and Staphylococcus aureus and nine gramnegative bacteria : Vibrio cholerae, Pseudomonas aeruginosa, Escherichia coli, Enterobacter sakazakii, Enterobacter cloacae, Proteus mirabilis, Citrobacter freundii, Klebsiella oxytoca and Serratia odorifera were tested in the screning. The microorganisms were isolated from the laboratories of microbiology of Yessad Khaled and Meslem Tayeb hospitals (Mascara, Algeria) and identify using the MALDI-TOF-SM except Listeria innocua and Staphylococcus aureus were obtained from Department of Food Technology and Nutrition, Catholic University of Murcia (Spain)

\section{Evaluation of antibacterial activity and Minimum Inhibitory Concentration (MIC)}

In vitro antimicrobial activity of the twelve extracts of Ficus carica dry fruits was studied against 14 pathogenic microbial strains by using the disc diffusion method according to Bauer et al. (1966). For this study, Gentamycin discs were used as positive and DMSO as negative control. Each standardized inoculum $(0.5$ McFarland) was melted with Muller Hinton agar cooled to $48^{\circ} \mathrm{C}$ and poured into sterile Petri dishes (Chanda and Kaneria, 2011). Blank discs were impregnated with the extracts already dissolved in pure DMSO at concentrations of 80, 40, 20 and $10 \mathrm{mg} / \mathrm{ml}$ in order to return them to the surface of the previously inoculated agar of each microorganism. Antimicrobial activity was recorded by measuring the clear inhibition zones around each disc after an incubation of $37^{\circ} \mathrm{C}$ for 24 hours (Aimahy et al., 2003)

The second method to evaluate the antibacterial activity was by using 96 Well microliter plates (Mitscher et al., 1972). A dilution series was performed in the wells ranging from $150 \mu \mathrm{g} / \mathrm{ml}$ to $1.17 \mu \mathrm{g}$ (Lazreg Aref et al., 2010).

\section{Antimicrobial effects of combined extracts}

This technique allowed to study the combination of 12 extracts in order to have the most relevant antimicrobial activity using 2 different methods: microplates and diffusion on agar medium. The interpretation of the results was based on the growth of bacteria at different concentrations of combined extracts to conclude the synergistic effect, cumulative, indifferent and antagonistic according to the FIC values: FIC $\leq 0.5, \mathrm{FIC}=0.5-1, \mathrm{FIC}=1-4$ and $\mathrm{FIC} \leq 4$ respectively (Climo et al. 1999).

\section{Statistical analysis}

The data were analyzed statistically using one-way analysis of variance (STAVIEW version 5.0, Abacus Concepts, Berkeley, CA) and Student's t-test. The results are given as arithmetic mean \pm SEM. The correlation between antioxidant capacity and polyphenol content was determined by the Pearson correlation $\left(\mathrm{R}^{2}\right.$ value).

\section{RESULTS}

\section{Physicochemical Analysis}

Investigations on the phytochemical screening of Ficus carica fruits of the three samples indicated on table 1 , the presence of flavonoids, tannins, coumarines and alkaloids, total phenols coumpond and anthocyanins in faint quantity, while saponins, Steroids and triterpenoids are totaly absent. Previous studies realized by Vaya et Mahmood (2006), Teixeira et al. (2006) showed that the aqueous extract of Ficus carica contains alkaloids, flavonoids and coumarins. Ficus exasperate includes alkaloids and tannins without any traces of saponosides or sterols (Engwa et $a l ., 2015)$. 
Table 1 Results of phytochemical screening of Ficus carica samples

\begin{tabular}{lccc}
\hline & El-Keurt & Ain Farès & Sidi Bendjebbar \\
\hline Phenols & \pm & \pm & \pm \\
Flavonoids & + & + & + \\
Tannins & + & \pm & \pm \\
Coumarines & + & + & + \\
Alkaloids & + & + & + \\
Saponins & - & - & - \\
Anthocyanins & + & \pm & - \\
Steroids and & - & - & - \\
Triterpenoids & - & & \\
\hline
\end{tabular}

+ Present, \pm traces, - absent.

\section{Total phenolic compound}

The TPC was determined by employing Folin-Ciocalteau reagent and was expressed as mg of gallic acid per 100g of dry fruit. The TPC of the three samples varied from 78 to $458 \mathrm{mg} \mathrm{GAE} / 100 \mathrm{~g}$ of $\mathrm{DM}$. The highest value was conferring to the methanolic extract of Sidi Bendjebbar sample and the lowest is the aqueous extract of Ain Farès (Fig.1). According to the work of Doha and Al-Okbi (2008), figs have the lowest polyphenol content with $920 \mathrm{mg}$ GAE / $100 \mathrm{~g}$ of DM compared to other plants eg rosewood that contains more than $8643 \mathrm{mg}$ GAE / $100 \mathrm{gr}$ MS The total polyphenol content studied by Bey and Louaileche (2015) ranges from $482.62 \mathrm{mg} \mathrm{GAE} / 100 \mathrm{gr}$ MS (Aberkane) to $644.11 \mathrm{mg}$ GAE / 100gr MS (Taghanimt) to reveal that the black fruits of Ficus carica $L$. are richer in polyphenols than the white samples. These values are higher than ours, since our values have not exceeded $458 \pm 0.42 \mathrm{mg} \mathrm{GAE} / 100 \mathrm{~g}$ DM.

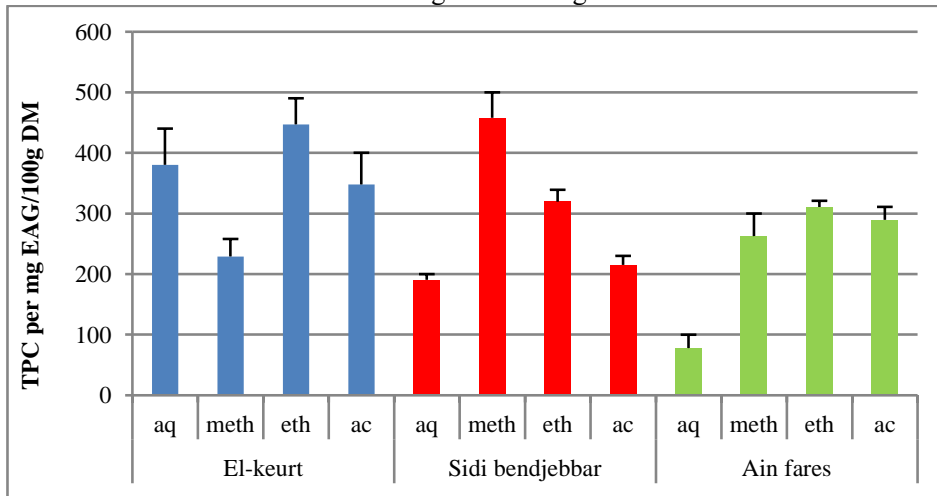

Figure1 Total polyphenol content (TPC) of Ficus carica extracts (mg GAE / 100 g DM) aq=aqueous ; eth=ethanolic ; meth=methanolic and ac=acetonic.

\section{Total flavonoid compound}

In this study, the amount of total flavonoids was expressed using the $\mathrm{AlCl}_{3}$ reagent and catechin as standard $\left(R^{2}=0,9937\right)$. The total flavonoids varied from $38.8 \pm 0.012 \mathrm{mg} \mathrm{CE} / 100 \mathrm{~g}$ DM as lowest value (methanolic extract of Ain Farès) to $228.22 \pm 0.27 \mathrm{CE} / 100 \mathrm{~g}$ DM as the highest value (acetonic extract of El-Keurt sample). The total flavonoids that Lamien-Meda et al. (2008) were able to detect in the Ficus sycomorus species of Burkina Faso had a value of $24.15 \pm 1.81 \mathrm{mg}$ $\mathrm{QE} / 100 \mathrm{~g}$ of fruit for the methanol extract and $33.15 \pm 1.79 \mathrm{mg} \mathrm{QE} / 100 \mathrm{~g}$ of fruit for the acetonic extract, which fits perfectly with our work where the acetonic extract of the three samples allowed to extract the highest content of flavonoids (fig.02). Ficus bengalensis had the highest level of flanonols with more than $3 \mathrm{mg}$ $\mathrm{QE} / \mathrm{g}$ of DM compared to the other used plants and a flavonoid level above our three samples with $5 \mathrm{mg}$ QE / g of dry extract (Sharma et $a l ., 2009$ ).

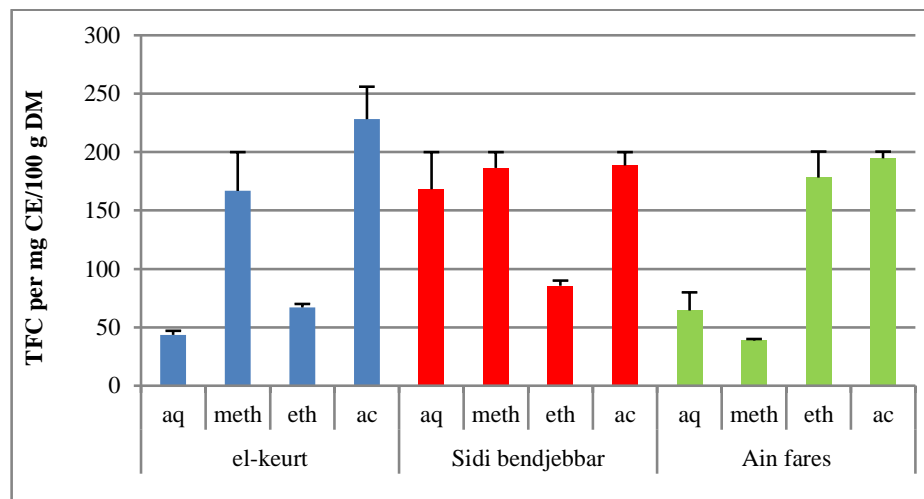

Figure 2 Total flavonoids content (TFC) of Ficus carica extracts (mg CE / $100 \mathrm{~g}$ DM) aq=aqueous ; eth=ethanolic; meth=methanolic and ac=acetonic.

\section{Condensed tannins content}

As depicted in Fig. 3, the highest total tannin content and the lowest value were observed in El-Keurt sample with $254,1 \pm 0.43 \mathrm{mg} \mathrm{CE} / 100 \mathrm{~g} \mathrm{DM}$ for the aqueous extract and $7.05 \pm 0.3 \mathrm{mg} \mathrm{CE} / 100 \mathrm{~g} \mathrm{DM}$ for the ethanolic extract. If we compare these results with other studies, we find that Debib et al. (2013) had a tannin content between 10 and $194 \mathrm{mg} \mathrm{GAE} / 100 \mathrm{~g}$ where the highest value was observed for the methanol extract of the two samples with 160 to $194 \mathrm{mg} \mathrm{GAE} / 100 \mathrm{~g}$ and the smallest is for extracts macerated with petroleum ether in contrast to our extracts since the lowest levels were in methanol extracts with a max of $122.35 \pm$ $2.16 \mathrm{mg} \mathrm{GAE} / 100 \mathrm{~g}$ DM.

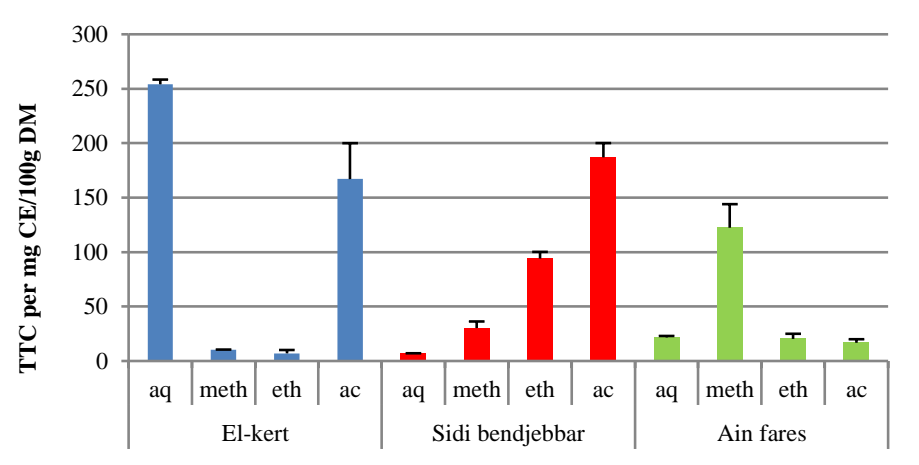

Figure 3 total tannin content (TTC) of Ficus carica extracts (mg CE / $100 \mathrm{~g} \mathrm{DM}$ ). aq=aqueous ; eth=ethanolic; meth=methanolic and ac=acetonic.

\section{Antioxidant activities}

The antioxidant capacities of the three varieties were determined using free radical scavenging capacity (DPPH), ferric reducing antioxidant power (FRAP) and total antioxidant activity (TAC).

\section{Total antioxidant activity}

This assay is based on the reduction of Mo (VI) to Mo (V) by antioxidant compounds and subsequent formation of a green phosphate/Mo(V) complex at acid pH (Pioci et al., 2011). Total antioxidant activity of all extracts was expressed as $\mathrm{mg}$ equivalent of gallic acid per $\mathrm{g}$ of dry mater by using different concentrations, a calibration curve was recorded, and the correlation coefficient $\left(R^{2}=0.9989\right)$.

According to the figure $\mathrm{n}^{\circ} 4$, the antioxidant capacity for Ficus carica fruits ranged from $50.5 \pm 0.12$ to $98.8 \pm 0.27 \mathrm{mg} \mathrm{AAC} / \mathrm{g} \mathrm{DM}$. It was observed that the highest values of this activity are obtained for the ethanolic extract of Ain Farès sample. In second position we find the same extract of Sidi Bendjebbar sample with 95.9 $\pm 0.2 \mathrm{mg} \mathrm{AAC} / \mathrm{g}$ DM but the last value was detected in Sidi Bendjebbar sample in comparison with ascorbic acid $99.8 \pm 0.13 \mathrm{mg} \mathrm{AAC} / \mathrm{g} \mathrm{DM}$. 


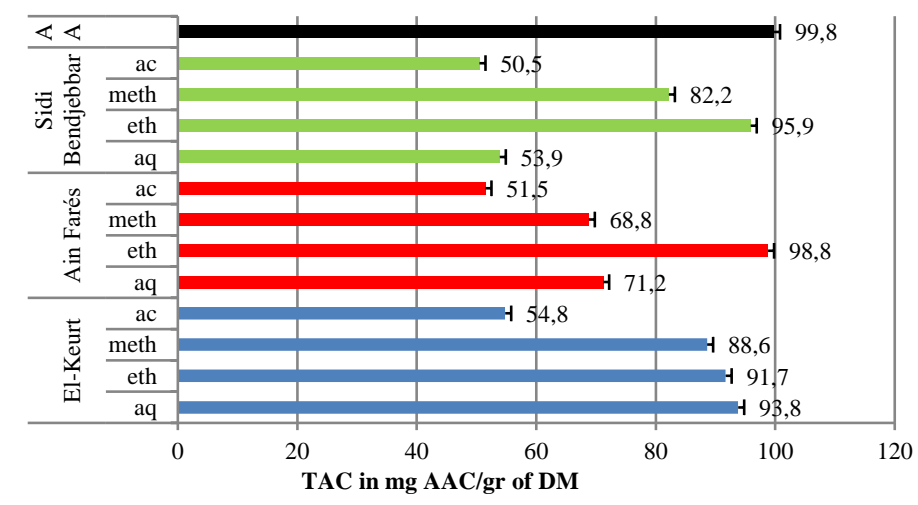

Figure 4 Total antioxidant capacity (TAC) of Ficus carica extracts (mg AAC / g $\mathrm{DM}) . a q=$ aqueous $;$ eth=ethanolic; meth=methanolic and ac=acetonic.

Caliskan and al. (2011) worked on different adhesions of Ficus carica L. They detected that TAC ranged from 3.9 to $16.1 \mathrm{mmol} \mathrm{Fe}^{2+} / \mathrm{Kg} \mathrm{FW}$ specifying that the adhesion "Siyah 5", which is characterized by a dark black fruit, contained the greatest amount of TAC among the 50 accessions tested. According to Konyaloglu and coll. (2005) works, the aqueous extract of the dried figs revealed the highest total antioxidant activity with $23,507 \pm 1,154 \mathrm{mM} \alpha$-tocopherol acetate / $\mathrm{g}$ of DM followed by methanol and ethanol extract with more than 17 and $14 \mathrm{mM}$ $\alpha$-tocopherol acetate / $\mathrm{g}$ of DM which is not suitable for our work since the ethanolic extracts are the most effective.

\section{DPPH radical scavenging activity}

In figure 5, ethanolic extract of El-Keurt sample chelated more than $88.1 \pm 0.03 \%$ of the DPPH radical with the lowest $\mathrm{IC}_{50}=0.0782 \mathrm{mg} / \mathrm{g}$ DM compared to the positive control with $\mathrm{IC}_{50}$ equal to $0.006 \mathrm{mg} / \mathrm{g} \mathrm{DM}$. This high percent of inhibition is explain by his high percent of total phenolic coupounds (the second position) and followed by methanolic extract of the same sample being the most effective sample which had an $\mathrm{IC}_{50}=0.1016 \mathrm{mg} / \mathrm{g} \mathrm{DM}$ and a pourcent of inhibition $84.6 \pm$ $0.04 \%$. The lowest percent was detected in ethanolic extract of the sample Sid Bendjebbar with a $1 / \mathrm{IC}_{50}$ closed to $2,458 \mathrm{mg} / \mathrm{g} \mathrm{DM}$

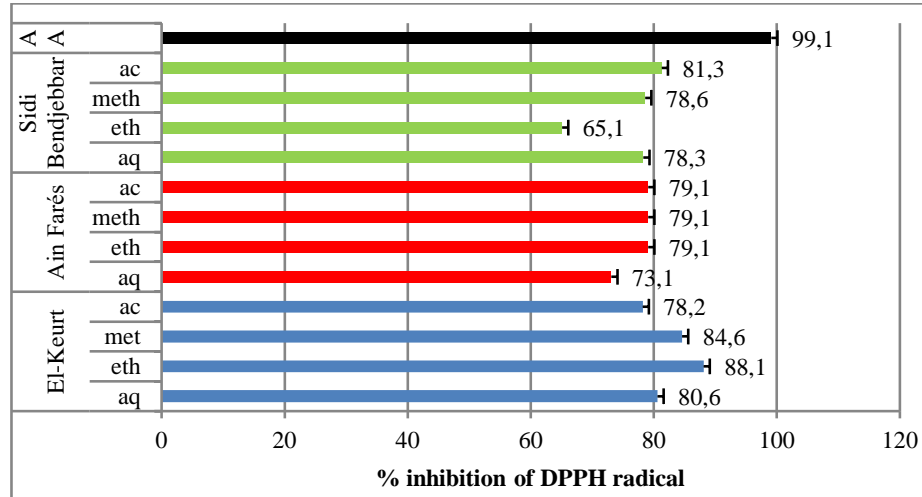

Figure 5 Pourcentage of inhibition of DPPH radical scavenging of Ficus carica extracts. Acid ascorbic (AA) was used as standart.

aq=aqueous $;$ eth=ethanolic ; meth=methanolic and ac=acetonic

In the studies of Konan et al.,(2014), it was found that the antioxidant activity value $\left(\mathrm{IC}_{50}\right)$ of Ficus dicranostyla was more than $38.4 \mu \mathrm{g} / \mathrm{ml}$. The antioxidant capacity evaluated by DPPH radical scavenging ranged from 3.19 to $87.09 \mathrm{mg}$ AAC/g of fw for MeOH extracts and from 4.99 to $107.29 \mathrm{mg} \mathrm{AAC} / \mathrm{g}$ of fw for the acetonic extracts (Lamien-Meda et al., 2008). In other work, the antioxidant activity of dried figs grown in Turkey was $1.087 \pm 11 \mathrm{mg} \mathrm{AAC} / 100 \mathrm{~g} \mathrm{DM}$ and that of fresh figs grown in Japan was $2.524 \pm 37 \mathrm{mg}$ AAC / $100 \mathrm{~g} \mathrm{DM}$ (Ishiwata et al., 2004). These results are in agreement with our work since we had values ranging from 2.458 to $12.787 \mathrm{mg} / \mathrm{g} \mathrm{DM}$.

\section{FRAP radical scavenging method}

In the FRAP method, the formation of an intense blue color where the intensity is relative to the amount of antioxidant reductants in the sample is mainly due to the reduction of ferric tripyridyltriazine to a ferrous complex detected at a wavelength of $593 \mathrm{~nm}$.. In relation to the solvent used, highest percent of inhibition of FRAP complex was found in acetonic extract of Ain Farès sample with $\mathrm{IC}_{50}$ equal to $1,179 \mathrm{mg} / \mathrm{g} \mathrm{DM}$ followed by the aqueous extract of El-Keurt sample with 1.24 $\mathrm{mg} / \mathrm{g} \mathrm{DM}$ in total agreement with the total antioxidant activity. The aqueous extract of the last sample (Sidi Ben Djebbar) is the least effective extract with an inhibition rate not exceeding $60 \%$ with antiradicalor activity $1 / \mathrm{IC}_{50}=2,389 \mathrm{mg} / \mathrm{g}$ DM (Table 2)

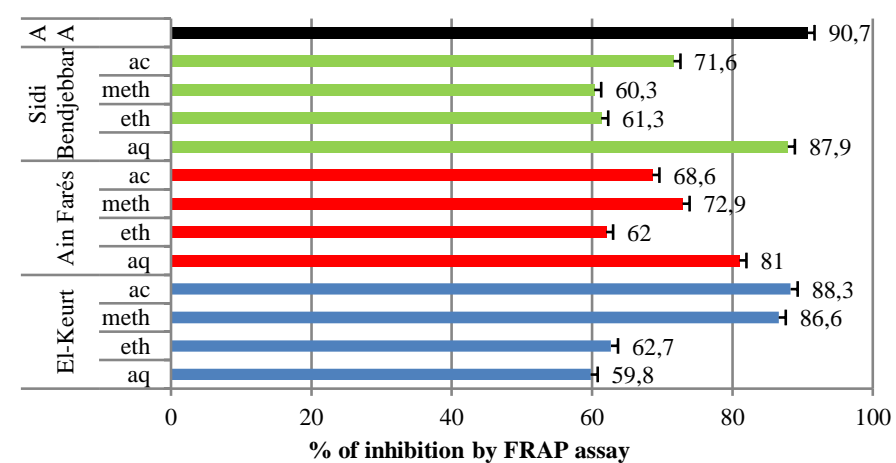

Figure 6 Pourcentage of inhibition by FRAP essay of Ficus carica extracts. Acid ascorbic $(A A)$ was used as standart.

aq=aqueous $;$ eth=ethanolic $;$ meth=methanolic and ac=acetonic.

Li fu et al., (2010) studied 56 plants from China including 2 fig species: Ficus benjamina and Ficus hispida to reveal their antioxidant activity using the iron reduction method which gave $\mathrm{IC}_{50}$ varying from $8.26 \pm 0.51 \mu \mathrm{mol} \mathrm{Fe}(\mathrm{II}) / \mathrm{g}$ to 6.26 $\pm 0.28 \mu \mathrm{mol} \mathrm{Fe}(\mathrm{II}) / \mathrm{g}$ respectively. The values obtained by Isaac Kingsley Amponsah in 2012 are more effective varying from $186.10 \pm 0.012$ to $760.00 \pm$ $0.023 \mu \mathrm{g} / \mathrm{ml}$ for the extracts with different solvents. The percentage of inhibition of DPPH $(78.65 \%)$ by the Ficus asperifolia species is higher than that found by the FRAP method (59.27\%). These results are similar to our results since the $\mathrm{IC}_{50}$ obtained by the DPPH method are the smallest and therefore the antioxidant activity is more important (Ojo and Akintayo, 2014).

Table $2 \mathrm{IC}_{50}(\mathrm{mg} / \mathrm{g}$ of $\mathrm{DM})$ and $1 / \mathrm{IC}_{50}(\mathrm{mg} / \mathrm{g}-1$ of $\mathrm{DM})$ values obtained in $\mathrm{DPPH}$ free radical scavenging assay and FRAP assay.

\begin{tabular}{|c|c|c|c|c|c|}
\hline \multirow[b]{3}{*}{ Ascorbic Acid } & \multirow[b]{3}{*}{ I } & \multicolumn{2}{|l|}{ DPPH } & \multicolumn{2}{|l|}{ FRAP } \\
\hline & & $\mathrm{IC}_{50}$ & $1 / \mathrm{IC}_{50}$ & $\mathrm{IC}_{50}$ & $1 / \mathrm{IC}_{50}$ \\
\hline & & 0,0061 & 163,934 & 0,0171 & 58,479 \\
\hline \multirow[t]{4}{*}{ El-Keurt } & $\mathrm{Aq}$ & 0,158 & 6,305 & 1,241 & 0,805 \\
\hline & Meth & 0,101 & 9,842 & 1,909 & 0,523 \\
\hline & Eth & 0,078 & 12,787 & 1,5 & 0,666 \\
\hline & Ac & 0,189 & 5,265 & 1,905 & 0,524 \\
\hline \multirow[t]{4}{*}{ Ain Farés } & $\mathrm{Aq}$ & 0,293 & 3,403 & 1,771 & 0,564 \\
\hline & Meth & 0,207 & 4,812 & 1,412 & 0,708 \\
\hline & Eth & 0,215 & 4,638 & 1,412 & 0,708 \\
\hline & Ac & 0,241 & 4,144 & 1,179 & 0,847 \\
\hline \multirow[t]{4}{*}{ Sidi Ben Djebbar } & $\mathrm{Aq}$ & 0,403 & 2,479 & 2,389 & 0,418 \\
\hline & Meth & 0,187 & 5,327 & 1,409 & 0,709 \\
\hline & Eth & 0,406 & 2,458 & 1,327 & 0,753 \\
\hline & Ac & 0,235 & 4,242 & 1,623 & 0,615 \\
\hline
\end{tabular}

eth=ethanolic; meth=methanolic and ac=acetonic.

Correlation: Table 3 shows linear relationship between antioxidant compounds and antioxidant activities; the less is the $\mathrm{IC}_{50}$, the higher is the antioxidant activity. Phenolic compounds appear to contribute significantly positive correlation to the TAC, DPPH and FRAP essay especially total tannins compounds (TTC) that had a strong correlation with DPPH radical assay for two samples (El-Keurt and Ain Farès) also with FRAP assay for the second sample $\left(\mathrm{R}^{2}=0.7855\right)$. Previous studies on other samples confirmed our findings (Wahid et al., 2010, Debib et al., 2013).

Table 3 Correlation between the different activities

\begin{tabular}{ccccc}
\hline & & El-Keurt & $\begin{array}{c}\text { Sidi } \\
\text { Bendjebbar }\end{array}$ & Ain Farés \\
\hline \multirow{2}{*}{ TAC } & TPC & 0,0022 & 0,3903 & 0,6429 \\
& TFC & 0,9541 & 0,1965 & 0,0021 \\
& TTC & 0,3404 & 0,0043 & 0,1009 \\
FRA & TPC & 0,4274 & 0,62 & 0,9328 \\
P & TFC & 0,3754 & 0,5924 & 0,0672 \\
& TTC & 0,018 & 0,7855 & 0,163 \\
DPP & TPC & 0,0013 & 0,9692 & 0,2262 \\
H & TFC & 0,4481 & 0,0061 & 0,0912 \\
\hline
\end{tabular}


The extracts of Ficus carica were determined quantitatively by a method

Identification and quantitative determination of the phenolic compounds in the

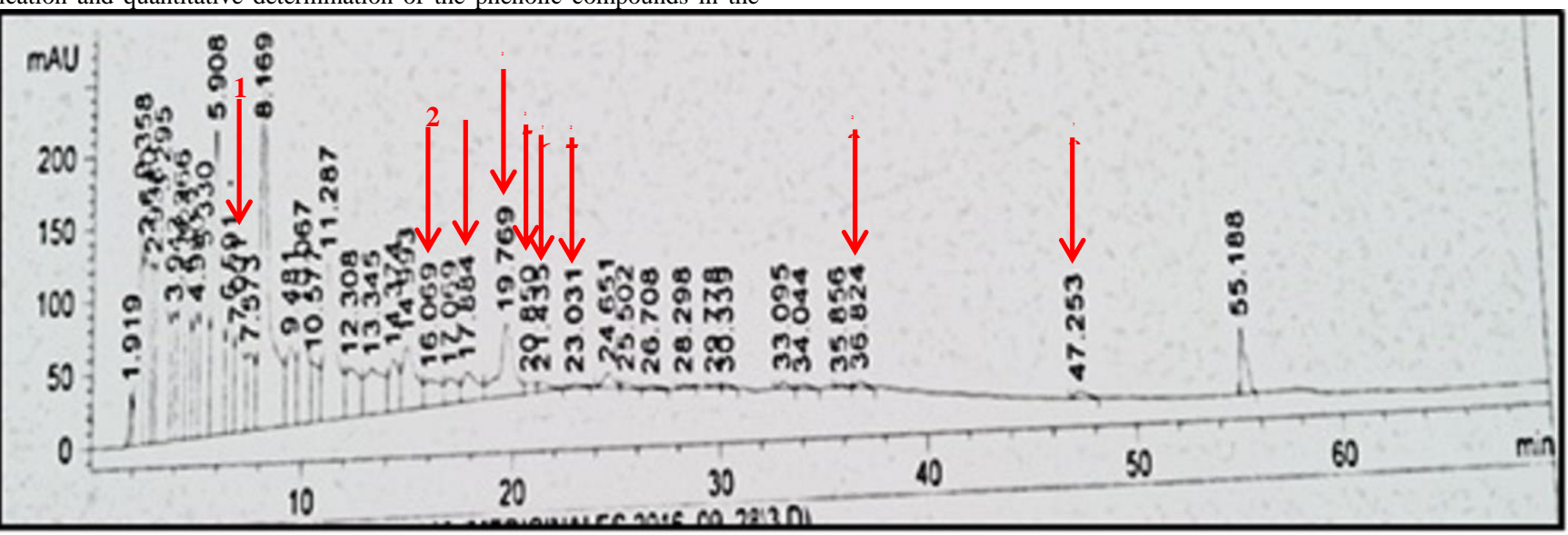

Figure 5 HPLC-DAD phenolic profile of aqueous extract of "El-Keurt" sample. Detection at $280 \mathrm{~nm}$. Peaks:1,gallic acid; 2, Catechin lidrata/catequin/Epigalocatechin viego;3,Procianidine B2; 4,cafein;5,vanillin ; 6, quercetin ; , epicatequin ; 8, gencond/Resreratol; 9, korempferol.

According to the results obtained in Fig. 5, the phenolic content composition of Ficus carica fruits remained incomplete since the main peaks have still not been determined. In addition, the technique we used for HPLC characterization as well as the conditions of analysis was unique and difficult to compare with the values of the literature and previous work.

\section{Antibacterial activity}

The antibacterial activity of aqueous and organic extracts shown in Table 04 was studied by determination of the minimum inhibitory concentration (MIC). These results showed that Citrobacter freundii was the most sensitive germ with $\mathrm{MIC}=$ $1.171 \mu \mathrm{g} / \mathrm{ml}$ but Listeria innocua was the most resistant germs with MIC more than $75 \mu \mathrm{g} / \mathrm{ml}$ follow by Enterococcus feacalis and Vibrio cholera with minimal bactericidal concentration equivalent to $300 \mu \mathrm{g} / \mathrm{ml}$.

Table 4 antibacterial activity of Ficus carica extracts

\begin{tabular}{lcccccc}
\hline Strain & G & ZI & MIC & MBC & $\begin{array}{c}\text { MBC/ } \\
\text { MIC }\end{array}$ & Extract the most effective \\
\hline Listeria innocua & 06 & 04 & 75 & 300 & 4 & el-keurt ethanolic \\
Bacillus subtilis & 15 & 11 & 4.68 & 150 & 32.05 & el-keurt, sidi bendjbbar ethanolics \\
Clostridium perfringens & 13 & 15 & 2.34 & 75 & 32.05 & bendjebbar ethanolic, el-keurt acetonic \\
Enterococcus faecalis & 11 & 07 & 37.75 & 150 & 7.94 & el-keurt, sidi bendjbbar ethanolics \\
Staphylococcus aureus & 11 & 10 & 18.75 & 150 & 8.01 & methanolic extracts \\
Vibrio cholera & 14 & 12 & 37.75 & 300 & 7.94 & el-keurt acetonic \\
Pseudomonas aeruginosa & 10 & 08 & 18.75 & 300 & 16.02 & el-keurt, sidi bendjbbar ethanolics \\
Escherichia coli & 12 & 10 & 2.34 & 75 & 32.05 & ethanolic, acetonic extracts \\
Enterobacter sakazakii & 13 & 15 & 9.37 & 150 & 16.02 & el-keurt acetonic \\
Enterobacter clocac & 15 & 10 & 2.34 & 75 & 32.05 & el-keurt acetonic \\
Proteus mirabilis & 09 & 10 & 2.34 & 150 & 64.1 & ethanolic and acetonic of el-keurt \\
Citrobacter freundii & 14 & 12 & 1.17 & 37.5 & 32.05 & el-keurt, sidi bendjbbar ethanolics \\
Klebsiella oxytoca & 12 & 11 & 4.68 & 75 & 16.02 & acetonic extract of sidi Bendjebbar \\
Serratia odorifera & 16 & 15 & 2.34 & 150 & 64.1 & methanolic extracts \\
\hline G: gentamycin as a positif control in mm, ZI: Zone of inhibition by disc diffusion method en mm, MIC: minimum inhibitory
\end{tabular}

concentration in $\mu \mathrm{g} / \mathrm{ml}, \mathbf{M B C}$ : minimal bactericidal concentration in $\mu \mathrm{g} / \mathrm{ml}$.

In the work of Jasmine R et al. (2014), the ethanol extract of Ficus carica showed an antimicrobial activity more than the methanol extract which corresponds to our results because ethanolic extracts especially El-Keurt and Sidi Bendjebbar were the most effective extracts and they can inhibit the majority of germes tested exclusively gram-negative bacteria.

$K$. pneumonae and E.coli revealed a significant resistance to the ethanolic extract of the figs in the study of Rashid and coll. (2014) highlighting the results that were found since these two strains had MBCs of $75 \mathrm{mg} / \mathrm{ml}$ and inhibition zones equal to $12 \mathrm{~mm}$ for each strain but this does not conform to the work of Kumar et al., 2013, where the ethanolic extract of Ficus palmata was effective only against $E$. coli without any inhibition zone for $S$. aureus also shown in the table above where the methanolic extract allowed its inhibition.

Truchan et al. (2015) worked on different Ficus species to evaluate its antibacteria activity against Pseudomonas aeruginosa revealing a range of inhibition between $10-15 \mathrm{~mm}$ unlike our study where the zone of inhibition did not exceed $10 \mathrm{~mm}$ for our extracts as well as that of the standart gentamycin. This is also confirmed by the experience of Ladipo et al.in 2011 stating that $P$. aeruginosa and E.coli have the highest MIC with $2 \mathrm{mg} / \mathrm{ml}$ for each against aqueous extracts of the leaves of F. exasperata which does not correspond to our results as showed in table 4.
The minimum inhibitory concentrations of methanolic extracts of Ficus carica against Listeria innocua, Enterococcus feacalis and Bacillus subtilis were th same with $3250 \mu \mathrm{g} / \mathrm{ml}$ (Okmen et al., 2014) which confused our study since these strains are the most resistant strains especially for the first strain (Listeria innocua) where the IMC is $75 \mu \mathrm{g} / \mathrm{ml}$ confirmed also by the aqueous and methanolic extracts of Ficus sycomorus latex that did not report any activity against E.feacalis just a moderate activity of ethanolic extract (Salem et al., 2014).

According to Ravishankar et al. (2012), Ficus bengalensis revealed significant activity against a group of gram positive and negative bacteria especially Klebsiella pneumonia with more than $20 \mathrm{~mm}$ of inhibition to be the most sensitive strain These results remains far from ours since the strain Klebiella oxytoca shown some resistance to our extracts which reveal a bacteriostatic activity on this strain giving a ratio $\mathrm{MBC} / \mathrm{MIC}$ more than 16 . Or strains with a $\mathrm{CMB} / \mathrm{MIC}$ ratio more than 32 this reveals a tolerance of the strain to our extract as B. subtilis, C. perfringens, $E$. coli, E. cloocae and C. freundii.

The FIC method that revealed the combination between our Ficus carica extracts and gentamycin against the strains studied, the results indicate a synergy and additivity between these extracts and the ATB since the FIC index is varied between 0.5 to 1 . The work of Young-Soo and Cha (2010) confirmed this because 
they found a synergy and additivity between the extracts of ficus carica and staph aureus resistant to methecillinnot to mention the work of Hosainzadegan et al (2012) who had the same result studying S.aureus, E.coli, P. aeruginisa and $K$. pneumoniae and Jeong and coll. in 2009 working on oral bacteria.

\section{DISCUSSION}

In the present study, free radical scavenging potential and total phenolic content of three samples of Ficus carica consumed in Mascara were evaluated Phytochemical investigation of the twelve extracts revealed the presence of chemical constituents that serve as defense mechanisms against predation by many microorganisms, insects and herbivores (Karlovsky, 2008), such as flavonoids, tannins, coumarines, alkaloids and anthocyanins. This diversity has been reported in Adeshina et al. (2009), Solomon et al. (2006); Oliveira et al. (2009). Recent studies have shown that polyphenol levels can be influenced by many environmental factors such as light intensity, mineral nutrition, dryness, and temperature fluctuation (Jaakola et al., 2002, Rabhi et al., 2013).

It was found that the best solvent is acetone according to the figures representing the level of polyphenols, flavonoids and tannins, which was approved by previous authors (Al-Farsi and Lee, 2008; Chaalal et al., 2012) and the use of solvents for maceration and extraction is still known as an effective means for isolation and selection of bioactive molecules (Engwa et al., 2015). Occasionally, Bay et al. (2014) revealed that solvent polarity is a premordial point in the extraction of polyphenols and antioxidants. Cell membranes are destroyed by the increase of acetone concentration that enhances the permeability of the solvent into the solid matrix (Zhang et al., 2006; Vatai et al., 2009). Besides, this solvent favored the extraction of less polar components (Cheok et al., 2012) but according to Motlhanka et al. (2012), methanol is very good for solvent extraction of polyphenols, tannins, flavones, anthocyanins.

Bucic-Kojic et al. (2011) showed that the main contributors of antioxidan capacities include polyphenols but not as much as a major element. For this reason, HPLC-DAD analyses were performed in order to determine the chemical composition of fig fruits in terms of polyphenols content. The data reported in figure 5, shows that El-Keurt fig sample is characterized by the presence of gallic acid, catequin, epigalocatechin, procyanidin, cafein, vanillin, quercetin, epicatequin and korempferol as the two other samples with moderate concentrations in agreements with Slatnar et al., 2011 that determined that the presence of this coumpounds can be influenced by sun-dried fruits which may affect the rate of organic acids, sugars, chlorogenic acid, catechin, epicatechin, kaempferol-3-O-glucoside, luteolin-8-C-glucoside, and total phenolic contents. In literature, the drying process of figs is the main cause of the destruction of phenolic compounds which directly influences their antioxidant effect (Apak et al., 2007; Nakilcioglu and Hisil, 2013). Accordingly, there may be a close relationship between the intensity of solar radiation and the biosynthesis of polyphenols in the plant explained by some researchers that long exposure to the sun and the amount of precipitation appear to be mostly involved in this natural phenomenon (Rabhi et al., 2013). On the other hand, as mentioned previously, the existence of other undetermined compounds with antioxidant activity (Faleh et al., 2012), such as those involved in the Maillard reaction (Billaud et al., 2005) can not be overlooked The antioxidant capacity of phenolic compounds results from the high redox potential and the ability to eliminate electron or hydrogen atoms from free radicals, which causes a break in the reaction chains, which then generates oxidative stress (Tsao \& Deng, 2004). The statistical analysis confirmed that the tested samples had different antioxidant powers because the highest antioxidant capacity was observed in the El-Keurt sample and the lowest in the Ain Farès sample. this diversity is probably due to the different techniques used for the study of the antioxidant power, difference of extractive technique and maceration by solvent without forgetting the effect of the interfering substances (ascorbic acid, saccharides and / or possibly carotenoids) (Stratil et al., 2007). But for Li Fu et al. (2010).These activities reflect an influence by certain factors such as the type of solvent and its polarity, the system used. A reliable antioxidant assessment protocol requires the measurement of several properties because most natural antioxidants are multifunctional. It is therefore essential to make a global determination of the different antioxidants present in the plant to implement the various antioxidant mechanisms (Wong et al., 2006).

According to the available literature, there is no conclusive work confirming the correlation between phenol content and antioxidant capacity (Yu et al., 2002 Ruberto et al., 2007; Konan et al., 2014) but others have found a strong relationship between the two [Pinelo et al., 2005; Konyaloglu, 2005; Makris et al., 2007). It is uncertain which of the phenols and flavonoids exhibit the greatest antioxidant effect but no doubt that quercetin is a flavonoid with high antioxidant and biological properties (Puoci et al., 2011), epicatechin and catechin revealed significant biological activity and even preventive activity against cancer (Jankun et al., 1997), catechin studied by Graziani et al. (2005) was also prevented oxidative damage of human gastric epithelial cells, gallic acid and its glycosides are extremely well absorbed into the human body, compared with other polyphenols (Manach et al., 2005) and shows high antioxidant against cancer cells proliferation (Tomas-Barberan et al., 2000).
The antimicrobial activity of fig fruits may be due to the presence of several active principals previously mentioned explained by the fact that the ethanolic extract of El-Keurt had a remarkable antimicrobial activity against the majority of strains studied as well as the best antioxidant activity using both TAC and DPPH method also shown in many works that the ethanolic extract gave satisfactory antimicrobial activity (Sharma and Sharma, 2010). Generally, researchers have found that organic extracts (alcoholic) have a more remarkable inhibitory effect than aqueous extracts can be explained by the fact that alcohol is the best solvent for the extraction of active compounds (Jouda et al., 2015). Ethanol has always been the most effective solvent because of the high content of phenolic compounds. They attributed this observation to the high volatility of ethanol, which tends to extract more active compound from the sample than water (Ladipo et al., 2011).

The high antimicrobial act may be related to the presence of tannins, saponins, alkaloids and flavone aglycones (Jouda MM et al., 2015) and others like rutin, quercetin, luteolin, phenolic acids and phytosterols (Jeong et al.,2009; Rashid et al., 2014)

The overlap in the results of antibacterial activity from one plant extract to another can be attributed to the age of the plant used and therefore freshness of the plant materials studied, environmental factors (temperature, water, lighting), the season and time of harvest and also the drying method used before the extraction process (Jouda et al., 2015) or may be explained by the differences in cell well composition and or inheritance genes on plasmids that can be easily transferred among bacterial strains (Lazrag-Aref et al., 2010).

It is possible that these bacteria, both gram positive and gram negative responded well to the plants as they had not been exposed to the plants before, and therefore had not had the opportunity to develop resistance yet as they have to antibiotics over the years. (Jasmine et al., 2014)

\section{CONCLUSION}

The analysis of the three algerian Ficus carica samples (El-Keurt, Ain Farès and Sidi Bendjebbar) reveals a rich phytochimical profil and a high antioxidant effect that can be reported to the presence of various bioactive compounds (phenolic compounds, flavonoids and tannins). This study highlights traditional medicines for its therapeutic benefits specially the antimicrobial side. Apparently, the potential significance of fig samples studied is therefore as source of antioxidants that could help in reducing the level of oxidative stress and by extension prevents development of chronic diseases.

Acknowledgments: The author would like to thank all people who gave her enending support parents, husband, friends and teachers.

\section{REFERENCE}

Almahyl H. A., Rahmani M., Sukari M. A. and Ali A. M. Investigation on the Chemical Constituents of the leaves of Ficus elastica Roxb. and their antimicrobial activity. Pertanika J. Sci. \& Technol. 11(1): 57 - 63 (2003).

Adeshina G. O., Ebere Okeke C.L., Onwuegbuchulam N. O. and Ehinmidu J. O. (2010). Preliminary studies on antimicrobial activities of ethanolic extracts of Ficus sycomorus Linn. and Ficus platyphylla Del. (Moraceae). Int. J. Biol. Chem. Sci. 3(5): 1013-1020. https://doi.org/10.4314/ijbcs.v3i5.51080

Al-Farsi, M. A. and Lee C. Y. (2008). Optimization of phenolics and dietary fibre extraction from date seeds. Food Chemistry. 108: 977-985. https://doi.org/10.1016/j.foodchem.2007.12.009

Aswar M. et al. (2008). Antimicrobial activity of Ficus benghalensis. Pharmacologyonline 2: 715-725.

Apak R, Güçlü K, Demirata B, Özyürek M, Çelik SE, Bektasoglu B, Berker KI, Özyurt D.(2007). Comparative evaluation of total antioxidant capacity assays applied to phenolic compounds and the CUPRAC assay. Molecules, 12:1496-1547. Awolola G. V., Koorbanally N. A., Chenia H., Shode F. O. and Baijnath H. Antibacterial and anti-biofilm activity of flavonoids and triterpenes isolated from the extracts of Ficus sansibarica warb. Subsp. Sansibarica (Moraceae) extracts. Afr J Tradit Complement Altern Med. (2014) 11(3):124-131.

Ba K., Tine E., Destain J., Cissé N., Thonart P. Étude comparative des composés phénoliques, du pouvoir antioxidant de différentes variétés de sorgho sénégalais et des enzymes amylolytiques de leur malt. Biotechnol. Agron. Soc. Environ.2010, 14(1): 131-139

Bauer A., Kirby J., Sherris G. and Turck M.,(1966). Antibiotic susceptibility testing by a standardized single disk method. American Journal Clinicial Pathology . 45. https://doi.org/10.1093/ajcp/45.4_ts.493

Bey B. M., Meziant L., Benchikh Y., Louaileche H. Deployment of response surface methodology to optimize recovery of dark fresh fig (Ficus carica L., var Azenjar) total phenolic compounds and antioxidant activity. Food Chem. 2014; 162: 277-282. https://doi.org/10.1016/j.foodchem.2014.04.054

Bey M. B. and Louaileche H. A comparative study of phytochemical profile and in vitro antioxidant activities of dark and light dried fig (Ficus carica L.) samples. The Journal of Phytopharmacology 2015; 4(1): 41-48

Billaud C, Maraschin C, Peyrat-Maillard M-N, Nicolas J (2005). Maillard reaction products derived from thiol compounds as inhibitors of enzymatic browning of 
fruits and vegetables: the structure-activity relationship. Ann N Y Acad Sci 1043: 876-885. https://doi.org/10.1196/annals.1333.099

Brand-Williams W., Cuvelier M.E., Berset C. (1995) - Use of a free radical method to evaluate antioxidant activity. Lebensm.Wiss.u.Technol., 28:25-30

Bucci-Kojic A, Planinic M., Tomas S., Jokic S.,Mujic I., Bilic M. and Velic D.. Effect of Extraction Conditions on the Extractability of Phenolic Compounds from Lyophilised Fig Fruits (Ficus Carica L.). Pol. J. Food Nutr. Sci., 2011; 61(3): 195199. https://doi.org/10.2478/v10222-011-0021-9

Cansaran A. and Kaya O.F. (2010). Contributions of the ethnobotanical investigation carried out in Amasya district of Turkey (Amasya-Center, Baglarüstü, Bogaköy and Vermis villages; Yssiçal and Ziyaret towns). (Biodicon), Biology Diver. Concert, 3: 97-116.

Chaalal M., Touati N. and Louaileche H., (2012). Extraction of phenolic compounds and in vitro antioxidant capacity of prickly pear seeds. Acta Botanica Gallica 159: 4, 467-475. https://doi.org/10.1080/12538078.2012.758495

Cheok C. Y., Chin N. L., Yusof Y. A., Talib R. A. and Law C. L.(2012) Optimization of total phenolic content extracted from Garcinia mangostana Linn. hull using response surface methodology versus artificial neural network. Industrial Crops and Products. 40: 247-253.

Chanda S. and Kaneria M. (2011). Indian nutraceutical plant leaves as a potential source of natural antimicrobial agents. Science against microbial pathogens: communicating current research and technological advances: 1251-1259.

Chinedu FA., Uyai U., Emezie AU., Utoh-Nedosa AU. (2012). Anti-diarrhoeal, antispasmodic and phytochemical properties of ethanol extract of the leaves of Ficus exasperate. Asian J. Res. Pharm. Sci. 2 (1): 26-32.

Climo MW, Patron RL, Archer GL (1999) Combinations of vancomycin and betalactams are synergistic against staphylococci with reduced susceptibilities to vancomycin. Antimicrob. Agents Chemother., 43: 1747-1753.

Daniel M. and Topo E. (2012). Analysis of nutrients, total phenols and antioxidant activity of Ficus sansibarica warb. Fruits from eastern botswana. Journal of Drug Delivery \& Therapeutics. 2(6), 1-5. https://doi.org/10.22270/jddt.v2i6.318

Das K., Tiwari RKS., Shrivastava DK. (2010). Techniques for evaluation of medicinal plant products as antimicrobial agent: Current methods and future trends. J Med Plants Res. 4(2): 104-111. DOI: 10.5897/JMPR09.030.

Debib A., Tir-Touil A., Mothana R.A., Meddah B. and Sonnet P. Phenolic content, antioxidant and antimicrobial activities of two fruit samples of Algerian Ficus carica L. J. Food Biochem.2013; 1-9. https://doi.org/10.1111/jfbc.12039

Doha A. M. and Al-Okbi S. Y. (2008). Evaluation of anti-gout activity of some plant food extracts. Pol. J. Food Nutr. Sci. 58 (3): 389-395.

Engwa G. A., Tagbo R. N., Chukwuekezie C., Unaegbu M. and Unachukwu M. N. (2015). Comparative antimicrobial activity of ethanol and hexane leaf extracts of Ficus exasperata on five microbial isolates. Global Journal of Medical Research: B Pharma, Drug Discovery, Toxicology and Medicine. 15 (1): 20-28.

Evans W.C. (1996). Trease and Evans Pharmacognosy, 14th Ed.,(Bailiere Tindall W.B.) pp. 224-228, 293-309, 542-575, Sauders Company Ltd, London, U.K

Faleh E., Oliveira A. P., Valentão P., Ferchichi A., Silva B. M., Andrade P. B. (2012). Influence of Tunisian Ficus carica fruit variability in phenolic profi les and in vitro radical scavenging potential. Brazilian Journal of Pharmacognosy 22(6): 1282-1289. http://dx.doi.org/10.1590/S0102-695X2012005000132

Graziani G., D'Argenio G., Tuccillo C., Loguercio C., Ritieni A., Morisco F., Del Vecchio Blanco C., Fogliano V. and Romano M. (2005). Apple polyphenol extracts prevent damage to human gastric epithelial cells in vitro and to rat gastric mucosa in vivo. Gut.54: 193-200. https://dx.doi.org/10.1136\%2Fgut.2004.046292 Guarrera P.M. (2003). Food medicine and minor nourishment in the folk traditions of central Italy (Marche, Abruzzo and Latinum). Fitoterapia, 74:515-544

Hosainzadegan H., Alizadeh M, Karimi F and Pakzad P. Study of antibacterial effects of ripped and raw fig alone and in combination. Journal of Medicinal Plants Research. Vol. 6(14), pp. 2864-2867, 16 April, 2012. DOI: 10.5897/JMPR011.1478

Hubert J (2006). Caractérisation biochimique et propriétés biologiques des micronutriments du germe de soja Etude des voies de sa valorisation en nutrition et santé humaines. Thèse de doctorat en Sciences Ecologiques, Vétérinaires, Agronomiques et Bioingénieries. Spécialité: Qualité et sécurité des aliments. Toulouse.

Isaac Kingsley Amponsah B. (2012). Chemical constituents, anti-inflammatory, anti-oxidant and antimicrobial activities of the stem bark and leaves of Ficus exasperata (vahl). Doctoral thesis in Philosophy. Pharm (Hons.).

Ishiwata K, Yamaguchi T, Takamura H, Matoba T. (2004). DPPH radicalscavenging activity and polyphenol content in dried fruits. Food SciTechnol Res 10:152-156.

Jaakola L, Määttä K, Pirttilä AM, Törrönen R, Kärenlampi S, Hohtola A. (2002). Expression of genes involved in anthocyanin biosynthesis in relation to anthocyanin, proanthocyanidin, and flavonol levels during Bilberry fruit development. Plant Physiol. 130:729-739. https://doi.org/10.1104/pp.006957

Jankun J., Selman S.H., Swiercz R. and Skrzypczak-Jankun E. Why Drinking Green Tea Could Prevent Cancer. Nature (1997), 387, 561 https://doi.org/10.1038/42381

Jasmin R., Manikanda K., Brinda, Niveditha, Kalaivani, Thirupathi and Manikandan G.. Evaluating the effeciency of Ficus carica fruits agains a few drugs resistant bacterial pathogens. World Journal Of Pharmacy And Pharmaceutical Sciences. 2014. 3(2): 1394-1400

Jeong M.R., Y. H. Kim and Cha J.D. Antimicrobial Activity of Methanol Extract from Ficus carica Leaves Against Oral Bacteria. Journal of Bacteriology and Virology .2009. Vol. 39(2) pp.97-102. DOI 10.4167/ibv.2009.39.2.97

Jouda MM. Elbashiti T, Masad A and Dardona Z. (2015). Synergistic effect of Ficus sycomorus (Moraceae) leaf and stem-bark extracts against Some Selected Pathogens. International Journal of Scientific and Research Publications, Volume 5(12), pp: 492-496.

Julkunen-Tiitto R. (1985). Phenolics constituents in the leaves of northern willows: Methods for the analysis of certain phenolics. J. Agr. Food Chem., 33: 213-217. DOI: 10.1021/jf00062a013

Karlovsky P. (2008). Secondary metabolites in soil ecology. Springer Amazon Company; 244 - 245.

Konan Y, Witabouna K. M., Bassirou B., Kagoyire K . Antioxidant activity and total phenolic content of nine plants from Côte d'Ivoire (West Africa). Journal of Applied Pharmaceutical Science.2014, 4 (08):36-41. DOI: 10.7324/JAPS.2014.40807

Kumar A., Gularia R. and Bharadwaj A. Antibacterial screening of Ficus palmata Forsk. pure latex and its methanolic and ethanolic extracts. Indian journal of naturel products and ressources. Vol 4(4), december 2013, pp. 371-374.

Ladipo M.K., Doherty F.V. Heavy metal analysis and effect of the crude extract of the leaves of Brysocarpus coccineus and Ficus exasperata on some pathogenic organisms. International Journal of Biosciences (IJB). Vol. 1, No2, Pp. 17-26, 2011.

Lamien-Meda A, Lamien C. E., Compaoré M. M.Y., Meda R. N.T., Kiendrebeogo M., Zeba B., Millogo J. F. and Nacoulma O. G. Polyphenol content and antioxidant activity of fourteen wild edible fruits from Burkina Faso. Molecules.2008, 13: 581-594.

Lazreg Aref H., Bel Hadj Salah K., Chaumont J.P., Fekih A.W., Aouni M. and Said K. (2010). In vitro antimicrobial activity of four Ficus carica latex Fractions against resistant human pathogens (antimicrobial activity of ficus carica latex). Pak. J. Pharm. Sci., Vol.23, (1), pp.53-58.

$\mathrm{Li}$ Fu, Bo-Tao Xu, Xiang-Rong Xu, Xin-Sheng Qin, Ren-You Gan and Hua-Bin Li. Antioxidant capacities and total phenolic contents of 56 wild fruits from south China. Molecules. 2010:15, 8602-8617. doi: 10.3390/molecules15128602.

Mahmoudi S. KHALI M. A et Mahmoudi N. Etude de l'extraction des composés phénoliques de différentes parties de la fleur d'artichaut (Cynara scolymus L.) Nature \& Technologie B-Sciences Agronomiques et Biologiques. 2013, 9: 35 - 40 Makris D.P., Boskou G., Andrikopoulos N.K., Polyphenolic content and in vitro antioxidant characteristics of wine industry and other agri-food solid waste extracts. J. Food Compos. Anal., 2007, 20: 125-132.

Manach C., Williamson G., Morand C., Scalbert A., Remesy C. Bioavailability and bioefficacy of polyphenols in humans. I Review of 97 bioavailability studies Am. J. Clin. Nutr. 2005, 81: 230S-242S. DOI: 10.1093/ajcn/81.1.230S

Mawa S, Husain K., and Jantan I.. Ficus carica L. (Moraceae): Phytochemistry, traditional uses and biological activities. Hindawi Publishing Corporation Evidence-Based Complementary and Alternative Medicine. 2013, 1-8 http://dx.doi.org/10.1155/2013/974256

Mitscher LA, Leu RP, Bathala MS, Wu WN, Beal JL and White R (1972). Antimicrobial agents from higher plants. I: Introduction, rational and methodology.Lloydia, 35: 157-166.

Nakilcioglu E. and Hışıl Y. Research on the phenolic compounds in Sarilop (Ficus carica L.) Fig sample. GIDA. 2013,38 (5): 267-274. doi: 10.5505/gida.2013.08208 Nasar A., Vishwakarma P. K., Ikhan, and M Sohaib, In vitro antibacterial, antifungal and phytotoxic activities of Ficus carica methanolic leaves extracts, Int.J.Curr.Biotechnol., 2014, 2(2):11-15

Ojo OA, Akintayo CO. Assessment of antioxidant activity of Ficus asperifolia Miq aqueous extract - In vitro studies. The JPhytopharm, 2014; 3(1): 16-21.

Okmen G., Turkcan O., Erdal P. and Isik D. The non-enzymatic antioxidant activities of Ficus carica L. Subsp. Carica leaves and its antimicrobial activities against food pathogens. International Journal of Pharmaceutical Sciences and Research. 2014; Vol. 5(12): 5145-5150.

Oliveira AP, Valentão P, Pereira JA, Silva BM, Tavares F, Andrade PB. (2009). Ficus carica L.: Metabolic and biological screening. Food Chem Toxicol, 47:28412846. doi: $10.1016 /$ j.fct.2009.09.004

Olthof M.R., Hollman P.C.H., Buijsman M.N.C.P., van Amelsvoort J.M.M., Katan M.B. Chlorogenic acid, quercetin-3-rutinoside and black tea phenols are extensively metabolized in humans. J. Nutr. 2003, 133, 1806-1814.

Oyaizu, M. (1986). Studies on products of browning reactions: antioxidative activities of products of browning reaction prepared from glucosamine. Japanese Journal of Nutrition, 44, 307-315. http://dx.doi.org/10.5264/eiyogakuzashi.44.307 Prieto P, Pineda M, Aguilar M (1999): Spectrophotometric quantation of antioxidant capacity through the formation of a phosphomolybdenum complex: Specific application to the determination of vitamin E. Analytical Biochemistry 269: 337-341. https://doi.org/10.1006/abio.1999.4019

Puoci F., Iemma F., Spizzirri U. G., Restuccia D., Pezzi V., Sirianni R., Manganaro L., Curcio M. , Parisi O. I., Cirillo G. and Picci N.. Antioxidant activity of a 
mediterranean food product: "Fig Syrup". Nutrients. 2011, 3(3): 317-329. doi: 10.3390/nu3030317

Rashid K.I., Mahdi N.M., Alwan M.A. and Khalid L.B. Antimicrobial activity of fig (Ficus carica Linn.) leaf extract as compared with latex extract against selected bacteria and fungi. Journal of Babylon University /Pure and Applied Sciences.2014, 5 (22): 1620-1626.

Rabhi A., Falleh H., Limam F., Ksouri R., Abdelly C., and Raies A.. Upshot of the ripening time on biological activities, phenol content and fatty acid composition of Tunisian Opuntia ficus-indica fruit. African Journal of Biotechnology. 2013 12(40):5875-5885, DOI: 10.5897/AJB12.612

Ravishankar K. and Udaya Sree A. Evaluation of in-vitro antibacterial activity of Ficus bengalensis shoot tips extract. International Journal of Research in Pharmacy and Chemistry, 2012, 2(2): 452-455.

Ruberto G., Renda A., Daquino C., Amico V., Spatafora C., Tringali C., Tommasi N.D., Polyphenol constituents and antioxidant activity of grape pomace extracts from five Sicilian red grape cultivars.Food Chem., 2007, 100: 203-210. http://dx.doi.org/10.1016/j.foodchem.2005.09.041

Sharma RK, Sabanegh E, Mahfouz R, Gupta S and Thiyagarajan A. TUNEL as a test for sperm DNA damage in the evaluation of male infertility. Urology.2010, 76(6): 1380-13806. doi: 10.1016/i.urology.2010.04.036

Sharma M.C. and Sharma S. Phytochemical Screening and In vitro Antimicrobia Activity of Combined Citrus paradisi and Ficus carica Linn Aqueous Extracts. International Journal of Microbiological Research 1 (3): 162-165, 2010.

Salem W. M., Sayed W. F., Haridy M. and Hassan N. H. Antibacterial activity of Calotropis procera and Ficus sycomorus extracts on some pathogenic microorganisms. African Journal of Biotechnology. Vol. 13(32), pp. 3271-3280, 6 August, 2014. http://dx.doi.org/10.5897/AJB2014.13981

Sibel Konyaloglu,Husniye Saglam, and Bijen Kivçak. a-Tocopherol, Flavonoid, and Phenol Contents and Antioxidant Activity of Ficus carica Leaves. Pharmaceutical Biology .2005, Vol. 43, No. 8, pp. 683-686 https://doi.org/10.1080/13880200500383538

Singleton V.L., Orthofer R. and Lamuela-Raventos R.M. (1999): Analysis of tota phenols and other oxidation substrates and antioxidant $\mathrm{s}$ by means of FolinCiocalteu reagent. Methods Enzymol,299: 152-178. https://doi.org/10.1016/S0076-6879(99)99017-1

Slatnar A, Urska Klancar, Franci Stampar, and Robert Veberic. Effect of drying of figs (Ficus carica L.) on the contents of sugars, organic acids, and phenolic compounds. Journal of Agricultural and Food Chemistry. 2011, 9: 6-21. DOI: $10.1021 / \mathrm{jf} 202707 \mathrm{y}$

Solomon A, Golubowicz S, Yablowicz Z, Grossman S, Bergman M, Gottlieb HE, Altman A, Kerem Z, Flaishman MA. Antioxidant activities and anthocyanin content of fresh fruits of common fig (Ficus carica L.). J Agr Food Chem. 2006 54:7717-7723. https://doi.org/10.1021/jf060497h

Stratil P., Klejdus B., Kubán V., Determination of phenolic compounds and their antioxidant activity in fruits and cereals. Talanta. 2007, 71: 1741-1751. https://doi.org/10.1016/j.talanta.2006.08.012

Teixeira D.M., Patão R.F., Coelho A.V. And Da Costa C.T .(2006). Comparison between sample disruption methods and solid-liquid extraction (SLE) to extract phenolic compounds from Ficus carica leaves. J. Chromatogr. A. 1103:22-28 https://doi.org/10.1016/j.chroma.2005.11.047

Tomas-Barberan F.A., Clifford M.N. Dietary hydroxybenzoic acid derivativesnature, occurrence and dietary burden. J. Sci. Food Agric. 2000, 80:1024-1032 https://doi.org/10.1002/(SICI)1097-0010(20000515)80:7\%3C1024::AID-

JSFA567\%3E3.0.CO;2-S

Tsao R., Deng Z., Separation procedures for naturally occurring antioxidant $\begin{array}{lllll}\text { phytochemicals. } \quad J . & \text { Chromatogr. } & B, & 2004, & 812: 85-99\end{array}$ https://doi.org/10.1016/j.jchromb.2004.09.028

Vatai, T., Škerget, M. and Knez, Ž. (2009). Extraction of phenolic compounds from elder berry and different grape marc samples using organic solvents and/or supercritical carbon dioxide. Journal of Food Engineering 90: 246-254 http://dx.doi.org/10.1016/j.jfoodeng.2008.06.028

Vaya J, Mahmood S. Flavonoid content in leaf extracts of the fig (Ficus carica L.), Carob (Ceratonia siliqua L.) and Pistachio (Pistachia lentiscus L.). Biofactors. 2006, 28: 169-175.

Vinson J.A., Zubik L., Bose P., Samman N., Proch J. Dried fruits: excellent in vitro and in vivo antioxidant s. Journal of the American College of Nutrition. 2005, 24:44-50.

Wahid S, T.M.M. Mahmud, M. Maziah, A. Yahya and M. Ab. Rahim. Total phenolics content and antioxidant activity of hot water extracts from dried Ficus deltoidea leaves. J. Trop. Agric. and Fd. Sc. 2010, 38(1): 115- 122.

Wang J. et Mazza G. Effects of Anthocyanins and Other Phenolic Compounds on the Production of Tumor Necrosis Factor ? in LPS/IFN-?- Activated RAW 264.7 Macrophages. J. Agric. Food Chem. 2002, 50: 4183-4189. DOI: 10.1021/jf011613d

Wong S.P., Leong L.P., Koh J.H.W. Antioxidant activities of aqueous extracts of selected plants. Food Chem. 2006, 99: 775-783. https://doi.org/10.1016/j.foodchem.2005.07.058
Yu L., Haley S., Perret J., Harris M., Wilson J., Qian M., Free radical scavenging properties of wheat extracts. J. Agric. Food Chem., 2002, 50: 1619-1624. DOI: 10.1021/jf010964p

Young-Soo L. and Cha J.D. Synergistic antimicrobial activity of fig (Ficus carica) leaves extract against clinical isolates of Methicillin-Resistant Staphylococcus aureus. Kor. J. Microbial. Biotechnol. 2010, 38 (04): 405- 413.

Zhang, S., Chen, R., Wu, H. and Wang, C.Ginsenoside extraction from Panax quinquefolium L. (American ginseng) root by using ultrahigh pressure. Journal of Pharmaceutical and Biomedical Analysis.2006, 41: 57-63. https://doi.org/10.1016/j.jpba.2005.10.043

Zhishen J., Wengcheng T. and Jianming W.The determination of flavonoidcontents in mulberry and their scavenging effects on superior radicals, Food Chemistry.1999, 84: 555-559. 